\title{
Private Sector Development of Stem Cell Technology and Therapeutic Cloning
}

\author{
MICHAEL J. LYSAGHT, Ph.D., and ANNE L. HAZLEHURST, A.B.
}

\begin{abstract}
Based on data collected in June 2002, more than 30 biotechnology startup firms in 11 countries are pursuing commercial development of stem cell technology and therapeutic cloning. These firms employ 950-1000 scientists and support staff and spend just under \$200 million on research and development each year. The field has the look and feel of a high-tech cottage industry, with about half the startups employing fewer than 15 FTEs (full time equivalents). Funding is mostly from venture capitalists and private investors. Participants are geographically dispersed, with about $40 \%$ of the activity outside the United States. Focus is equally split between embryonic and adult stem cells. Taken as a whole, both the structure and scope of the private sector in stem cell research seem appropriate to the promise and development time frames of this important new technology.
\end{abstract}

\section{INTRODUCTION}

S TEM CELLS have emerged from condign obscurity to remarkable levels of prominence in both the scientific literature and lay consciousness. Reports in peer-reviewed journals are carried as front page news in the New York Times and are summarized on nightly national network news. Time, Newsweek, Business Week, The Atlantic Monthly, and many of their peer journals have all carried in-depth cover stories on stem cells. C-Span broadcast the full two-day National Academy of Sciences Workshop on the topic. Stem cells can fairly be said to have provided many scientists with their "fifteen minutes of fame."

Why all the attention, all of a sudden? First, of course, was Dolly and the paradigmatic revelation that a fully differentiated adult cell could be reprogrammed back to totipotent stem cell status. ${ }^{1}$ So far, at least, the technologies for cloning and stem cell biology are inseparable: it is not yet possible to create a clone without first creating a stem cell by nuclear transfer. Furthermore, advances in the understanding of basic stem cell biology have poten- tial relevance to therapeutic or reproductive cloning. Not long after Wilmut's announcement of Dolly came the techniques for isolating and culturing human embryonic stem cells as well as the capability to begin teasing the cultured cells down defined lineage pathways., ${ }^{2,3}$ Working largely with murine models, other investigators demonstrated that embryonic stem cells could be converted into tissue with functional utility in animal models of diabetes and Parkinson's disease. ${ }^{4,5}$ Other investigators pursued adult stem cells, discovering a hitherto unsuspected capacity for transdifferentiation. ${ }^{6-8}$ However, the plasticity of adult stem cells has become a controversial issue due to problems of separation, identification, proliferation, and cell fusion. Another controversial but certainly attention-getting issue arose with the reports of the cloning of an early stage human embryo by nuclear transfer $^{9}$ and the claim that parthenogenesis may eventually compete with nuclear transfer as a technique for cloning adult mammals. ${ }^{10}$ This dramatic progress was well summarized in an editorial in Nature last November by $\mathrm{N}$. DeWitt ${ }^{11}$ : "Stem cells are truly remarkable. They bridge the gulf between the fertilized egg that is our origin and

Center for Biomedical Engineering, Brown University, Providence, Rhode Island. 
the architecture that we become. They supply the cells that construct our bodies and, as we age, replenish worn out, damaged, and diseased tissues. They renew themselves, resisting the powerful pull toward diferentiation that overcomes more prosaic cells. Scientists now face the formidable task of . . . bringing stem cell therapies to the clinic."

Stem cell science and technologies are being pursued by the NIH and other government research agencies and in the private sector. This survey concerns the latter and is intended to quantify and discuss current private sector involvement in the development of stem cell technology: how many scientists and support staff are involved? How many firms? With what sort of financing? And with what patterns of activity and organization? No attempt is made to pick eventual winners and losers among the various companies or even to review and assess the validity of the underlying science. This field is evolving very rapidly, and it is important to note the analysis in this report is based on data that prevailed in mid-2002.

\section{METHODS}

To be eligible for inclusion in this study, firms needed to be significantly vested in stem cell technology. Typical focus areas included embryonic or adult stem cells, nuclear transfer and therapeutic cloning, banking or cord blood, and development or sale of enabling equipment and supplies. All firms identified by the NIH as custodians of "approved" stem cell lines were included. Not-for- profit organizations were excluded, as were firms involved in reproductive cloning of pets and livestock animals. Conventional bone marrow transplantation did not qualify. Firms that were peripherally or incidentally involved in stem cells were not included.

A list of qualifying firms was compiled from general awareness of the field, from keyword Web searches, from companies whose scientists presented at relevant technical or investor conferences (Pittsburgh Tissue Engineering Initiative, Society for Regenerative Medicine, Techvest), and from the trade literature. ${ }^{12}$ Once compiled, the list was circulated to and vetted by individuals knowledgeable in the field. The compilation is believed to be reasonably complete, although some smaller and newer firms will inevitably be missed in a field growing as rapidly as this.

A profile on each firm was then developed, including principal technical focus, date of founding, number of employees, source of funding, and, where appropriate, the fraction of the firm's efforts that was dedicated to stem cells. For public firms, this information was available from annual reports and SEC filings. For private firms, the information was obtained from the firm's Web site or by contacting the CEO (chief executive officer) or CFO (chief financial officer). Firms conducting operations in more than one country were asked for a breakdown of employees by geographic region. In a few cases, only a range of the number of full time equivalents (FTEs) was available; here, the midvalue of the range is reported. Wherever possible, information was doublechecked against information available from proprietary databases. ${ }^{13}$

Table 1. Stem Cell Companies listed by Size

\begin{tabular}{|c|c|c|}
\hline & $\begin{array}{l}\text { No. of FTEs }{ }^{\mathrm{a}} \\
\text { (aggregate) }\end{array}$ & $\begin{array}{l}\text { Estimated spending } \\
\text { (US\$, Millions/year) }\end{array}$ \\
\hline $\begin{array}{l}\text { Firms with }<15 \text { FTEs } \\
\text { Befutur Technologies, Cardion, } \\
\text { Cythera, Curis, }{ }^{\text {b Infigen, }{ }^{\text {b }} \text { Ixion, }}{ }^{\text {b }} \\
\text { Morphogen, NeuralStem, SCS KK, } \\
\text { Stem Cell Sciences, Stem Cell } \\
\text { Pharmaceuticals, Stemron, StemSource, } \\
\text { Vistagen }\end{array}$ & 131 & $\$ 28$ \\
\hline $\begin{array}{l}\text { Firms with } 15-35 \text { FTEs } \\
\text { ACT, Bresagen, }{ }^{\text {b Develogen, }}{ }^{\text {, }} \\
\text { Gamida Cell, Kuorion Therapeutics, } \\
\text { Maria, NeuroNova, Primegen, } \\
\text { Reliance, Renuron, Stem Cells }\end{array}$ & 270 & $\$ 54$ \\
\hline $\begin{array}{l}\text { Firms with more than } 35 \text { FTEs } \\
\text { Anthrogenesis, ES Cell } \\
\text { International, Geron Neuronyx, } \\
\text { Osiris, PPL Therapeutics, } \\
\text { StemCell Technologies, ViaCell }{ }^{\mathrm{b}}\end{array}$ & 631 & $\$ 126$ \\
\hline
\end{tabular}

${ }^{\text {a}}$ FTE refers to full-time equivalent supporting stem cell technology.

${ }^{\mathrm{b}}$ Firms with additional employees working in other areas. 
Private firms were generally unwilling to disclose their annual spending rate. Accordingly, where not directly available, this number was estimated from a lumped sum correlation of $\$ 200,000$ in total annual company expenditure per employee per year. This correlation had been validated in earlier surveys of the tissue-engineering field. ${ }^{14,15}$

Capital value for public companies was calculated as the product of the number of shares times individual share value, as of June 30, 2002. Number of shares was obtained from company financial statements and share values from on-line listings. Share values denominated in foreign currencies were converted to dollars at the exchange rates prevailing on June 30, 2002. For firms involved in activities other than stem cells, the capital value was prorated according to the fraction of the firm's activity devoted to stem cells. This implicitly assumes that all of a firm's activities contribute equally to its capital value.

One firm in the survey, PPL Ltd., announced in April of 2002 its intention to sell or spin off its stem cell activities. Since the announced intention was to divest, rather than discontinue, operations and since the restructuring had not yet taken place, PPL"s stem cell activities are included in this report under PPL's name.

\section{RESULTS}

As of mid-2002, private sector research and development in stem cells is being conducted by $\sim 1000$ scientists and support staff in 33 firms, operating in 11 countries. Aggregate spending is $\$ 208$ million. Six of the 33 firms are public; the remaining are private. Capital value of the public companies, prorated for their involvement in stem cells, is $\$ 180$ million, although the largest firm is responsible for well over half this total.

The Appendix lists the firms, gives their locations and Web sites, lists the number of employees, and provides a thumbnail sketch of each firm's activities. Table 1 classifies firms by size: 14 firms have fewer than 15 FTEs and spend a combined $\sim \$ 28$ million dollars per year; 11 firms have between 15 and 35 FTEs and spend in aggregate $\sim \$ 54$ million dollars per year; and 8 have more than 35 employees and spend an aggregate of $\sim \$ 126$ million per year. Figure 1 contains piecharts illustrating the proportion of firms in different stem cell activities, the fractions working on adult versus embryonic stem cells, and the geographical distribution of firms and employees. Table 2 lists the firms serving as repositories for "approved" human stem cell lines, ie those which can be used in federally funded US research. Table 3 summarizes the total and prorated capital value, as of the close of the second quarter of 2002, for those firms that are publicly traded.

\section{Stem Cell Research Category}

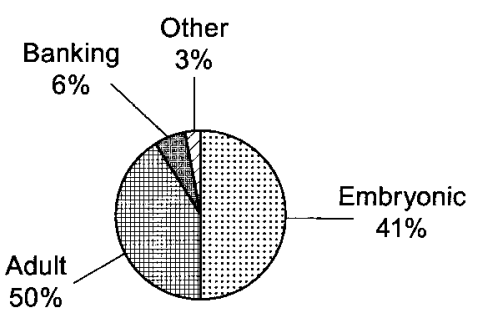

\section{Privately Held vs. Publicly Held}

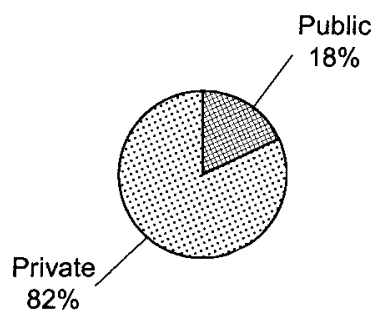

\section{Location of FTE's}

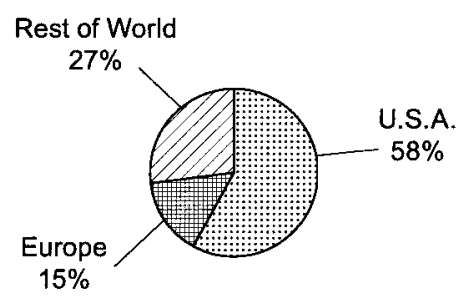

FIG. 1. Pie charts illustrating various industry characteristics.

\section{DISCUSSION}

Approximately 1000 FTEs and their associated costs is a substantial commitment but the net involvement of the private sector is nevertheless quite modest. Aggregate stem cell activity in the private sector is six times smaller than the total funds devoted each year to tissueengineering research and development. It is approximately the size of the staff that a pharmaceutical company would deploy for a single drug for each of the dozen years required to bring a lead compound to markets. And 
Table 2. Firms Serving as Custodians for NiH-Approved Embryonic Stem Cell Lines

Number of

Company approved cell lines

Bresagen

4

CyThera

9

ES Cell International

9

Geron

Maria Biotech

7

Reliance Life Sciences

it represents less than $1.5 \%$ of the annual research budget of Pfizer, a single drug company.

The size distribution of the individual firms is also telling. Companies with fewer than 15 employees (a broad plurality of stem cell companies) are really just getting started. By the time a firm has 15-35 employees it can conduct discovery-level science and highly productive firms of this size can certainly impact a field and create increments in shareholder value through intellectual property. However, the actual discovery, definition, development, and regulatory management of a product are extremely labor intensive. It would be highly unusual for a company to be successful at these latter activities with fewer than 100-150 employees.

Given their size and resources, what most stem cell firms are doing is developing technologies rather than products. The rationale is that such technologies will have realizable value as the field grows and matures. Companies are also investing in "squatter sovereignty" with the intention of developing infrastructure, experience, and trade skills that will allow them to participate in or even dominate a potentially explosive area of future biomedicine. Although high risk, these business models appear sound. In the absence of defined products a "small is beautiful" approach to stem cell startups may be appropriate.

A few firms, for example, Osiris, do have defined products, and others are selling services such as neonatal stem cell banking, while still others make and sell the specialized equipment needed for nuclear transfer. But these are exceptions; most activity is centered in pure-play technology development firms.

Most of the startups are private and thus funded by capital from angels, venture groups, and mezzanine financiers. Six are public: three raised their funds as stem cell firms (Bresagen, Geron, and Renouron) and three (Curis, PPL, and Stem Cell, Inc.) raised funds under a different persona and subsequently moved their activities wholly or partially into stem cells. Given the current condition of the stock market, not very much can be read into the current capital value of public stem cell companies. The soundest conclusion is that the market appears to be lumping these companies together with other biotech startups, and that stem cell firms trade neither at a premium or discount over other early-stage biotech startups. The constant calliope of publicity about stem cells has not led to a rash of IPOs ... which is probably a good thing. More disturbing is the lack of corporate partnerships or other flow of resources from large established pharmaceutical or medical device companies into stem cells. This source of revenue has been critical to the success of biotechnology in the past and will likely prove necessary for stem cells in the future.

Stem cell firms are highly diversified in both their technology approaches and geographical bases. The split of focus between adult cells and embryonic cells is about equal, at least in the number of firms working on each (see Fig. 1). This would seem to refute the common wisdom that embryonic stem cells are not "investable," although only time will tell if early investment is sustainable. The broad geographic base is also noteworthy. Some countries are distinctly more hospitable to embryonic stem cells and therapeutic cloning than others. Among countries that have established policies, the United Kingdom, Sweden, Israel, and Japan are the most permissive, while Germany and the United States are the

Table 3. Capital Value of Public Firms ${ }^{a}$

\begin{tabular}{lccccc}
\hline & $\begin{array}{c}\text { Shares outstanding } \\
(\text { US\$, millions) }\end{array}$ & $\begin{array}{c}\text { Share price } \\
\text { where listed }\end{array}$ & $\begin{array}{c}\text { Share price } \\
(\text { US\$) }\end{array}$ & $\begin{array}{c}\text { Capital value } \\
\text { (US\$, millions) }\end{array}$ & $\begin{array}{c}\text { Pro-rated capital value } \\
(\text { US\$, millions) }\end{array}$ \\
\hline BresaGen (35\%) & 46 & Aus\$0.78 & $\$ 0.44$ & $\$ 20$ & $\$ 7$ \\
Curis $(13 \%)$ & 32 & $\mathrm{US} \$ 1.22$ & $\$ 1.22$ & $\$ 39$ & $\$ 5$ \\
Geron $(100 \%)$ & 24 & $\mathrm{US} \$ 4.58$ & $\$ 4.58$ & $\$ 112$ & $\$ 112$ \\
PPL Therapeutics $(20 \%)$ & 118 & $£ 0.18$ & $\$ 27$ & $\$ 31$ & $\$ 6$ \\
Reneuron $(100 \%)$ & 39 & $£ 0.10$ & $\$ 0.12$ & $\$ 4$ & $\$ 4$ \\
Stem Cells $(100 \%)$ & 24 & $\mathrm{US} \$ 1.62$ & $\$ 1.62$ & $\$ 39$ & $\$ 39$ \\
\hline
\end{tabular}

aNotes: (1) Data are for last day of trading in the second quarter of 2002. (2) Conversion rates: 0.56 Australian dollar = 1 US dollar; 1.52 pounds $=1$ US dollar. (3) In column 1, each number in parentheses represents the fraction of company activities committed to stem cells. The prorated capital value is the total value times this fraction. See text. 
most constraining. Capital and scientists are likely to gravitate toward the region or environment where they can best flourish. Hence, the existence of a geographically dispersed industry ensures that restrictive legislation in one region will not stop the science from advancing.

The private sector is just one of many sources of stem cell research and development. Government agencies both perform work in their own laboratories and fund research in universities and research institutes. Quasi-public and not-for-profit laboratories also support stem cell research. No total of public sector spending on stem cells seems to be available. Based on the number and impact of publications in the peer-reviewed literature, it would appear that publicly supported stem cell research equals or exceeds that of the private sector. This pattern differs from that in other areas of tissue engineering, where support has always come almost entirely from the private sector. Since the public and private sectors have different goals, different priorities, different time frames, and different constraints, a balance between the two seems very sensible. Genomics research is a good example of how a combination of critical mass research in both sectors can accelerate development in a field.

Private sector activity in stem cells has emerged as a small, clearly identifiable high tech cottage industry. If the past history of biotech startups is a guide, these firms are attended by zeal, focus, high energy, excitement, and enthusiasm. Their relatively small size is likely an advantage at the current stage of development. If, and when, the field of stem cell research achieves a clinically important role in 21 st century healthcare, the commitment and belief of these early pioneers may indeed be amply rewarded.

\section{REFERENCES}

1. Campbell, K.H., McWhir, J., Ritchie, W.A., Wilmut. Sheep cloned by nuclear transfer from a cultured cell line. Nature 380, 64, 1996.

2. Thomson, J.A., Itskovitz-Eldor, J., Shapiro, S.S., Waknitz, M.A., Swoergoe, K.K., Marshall, V.V., and Jones, J.M. Embryonic stem cell lines derived from human blastocysts. Science 282, 1145, 1998.

3. Shamblott, M.J., Axelman, J., Wang, S., Bugg, E.M., Littlefield, J.W., Donovan, P.J., Blumenthal, P.D., Huggins, G.R., and Gearhart, J.D. Derivation of pluripotent stem cells from cultured human primordial germ cells. Proc. Natl. Acad. Sci. U.S.A. 95, 13726, 1998.
4. Lumelsky, N., Blondel, O., Laeng, P., Velasco, I., Ravin, R., and McKay, R. Differentiation of embryonic stem cells to insulin-secreting structures similar to pancreatic islets. Science 292, 1389, 2001.

5. Kim, J.H., Auerbach, J.M., Rodriguez-Gómez, J.A., Velasco, A., Gavin, D., Lumelsky, N., Lee, S.N., Nguyen, J., Sánchez-Pernuate, R., Bankiewicz, K., and McKay, R. Dopamine neurons derived from embryonic stem cells function in an animal model of Parkinson's disease. Nature 418, 50, 2002.

6. Zuk, P.A., Zhu, M., Mizuno, H., Huang, J., Futrell, J.W., Katz, A.J., Benhaim, P., Lorenz, H.P., and Hedrick, M.H. Multilineage cells from human adipose tissue: Implications for cell-based therapies. Tissue Eng. 7, 211, 2001.

7. Jiang, B., Jahagirdar, R., Reinhardt, L., Schwartz, R.E., Keene, C.D., Ortiz-Gonzalez, X.R., Reyes, M., Lenvik, T., Lund, T., Blackstad, M., Du, J., Aldrich, S., Lisberg, A., Low, W.C., Largaespada, D.A., and Verfaillie, C.M. Pluripotency of mesenchymal stem cells derived from adult marrow. Nature 418, 41, 2002.

8. Orlic, D., Kajstura, J., Chimenti, S., Jakoniuk, I., Anderson, S.M., Li, B., Pickel, J., and McKay, R. Bone marrow cells regenerate infracted myocardium. Nature 410, 701, 2001.

9. Cibelli, J.B., Lanza, R.P., West, M.D., and Ezzell, C. The first cloned embryo. Sci. Am. 286, 44, 2002.

10. Cibelli, J.B., Grant, K.A., Chapman, K.B., Cunniff, K., Worst, T., Green, J.L., Walker, S.J., Gutin, P.H., Vilner, L., Tabar, V., Dominko, T., Kane, J., Wettstein, P.J., Lanza, R.P., Studer, L., Vrana-Kent, E., and West, M.D. Parthenogenetic stem cells in nonhuman primates. Science 195, 819, 2002.

11. DeWitt, N. Stem cells. Nature 414, 87, 2001.

12. Stem Cell Research News. Leesburg, VA: Data Trends Publications http://www.stemcellresearchnews.com/

13. Alternative Investor, San Francisco, CA. http://www.venturesource.com

14. Lysaght, M.J., Nguy, N., and Sullivan, K. An economic survey of the emerging tissue engineering industry. Tissue Eng. 4, 231, 1998.

15. Lysaght, M.J., and Reyes, J. The growth of tissue engineering. Tissue Eng. 7, 485, 2001.

Address reprint requests to: Michael J. Lysaght, Ph.D. Center for Biomedical Engineering GB-393, Brown University Providence, RI 02818

E-mail: Lysaght@Brown.edu 


\section{APPENDIX}

\section{Firms Conducting Stem Cell Research and Development as of Mid-2002}

Company

Advanced Cell Technology

(Worcester, MA)

Anthrogenesis Corporation

(Cedar Knolls, NJ)

Befutur Technologies

(Case Postale, Switzerland)

BresaGen

(Adelaide, Australia/Athens, GA)

Cardion

Erkath, Germany/Boston, MA)

Curis

Cambridge, MA)

CyThera

(San Diego, CA)

Develogen

(Gottingen, Germany)

ES Cell International

(Melbourne, Australia)

Gamida Cell

(Jerusalem, Israel)

Geron

(Menlo Park, CA)

Infigen

(Deforest, WI)

Ixion Biotechnology

(Alachua, FL)

Kourion Therapeutics

(Duesseldorf, Germany)

Maria Biotech Company

(Seoul, Korea)

MorphoGen Pharmaceuticals

(San Diego, CA)

NeuralStem Biopharmaceutical

(Gaithersburg, MD)

NeuroNova

(Stockholm, Sweden)

Neuronyx

(Malvern, PA)

Osiris

(Baltimore, MD)

PPL Therapeutics

(Scotland/Virginia)

Primegen

(Santa Ana, CA)

Reliance Life Sciences

(Bombay, India)

Reneuron

(Surrey, UK)

SCS KK

(Kobe, Japan)

Stem Cell Sciences (SCS)

(Melbourne, Australia)

Web address

$F{ }^{\mathrm{a}} \mathrm{s}^{\mathrm{a}}$

Cell

Description

www.advancedcell.com

www.anthrogenesis.com

www.befutur.com

www.bresagen.com.au

www.cardion-ag.de

(70)

www.curis.com

(91)

www.cytheraco.com

www.develogen.com

www.escellinternational.com

www.gamida-cell.com

www.geron.com

www.infigen.com

www.ixion-biotech.com

www.kouriontx.com

www.mariabiotech.co.kr

www.morphogeninc.com

www.neuralstem.com

www.neuronova.com

www.neuronyx.com

www.osiristx.com

www.ppl-therapeutics.com

www.primegenbiotech.com

www.reneuron.com

www.stemcellsciences.com.au
14

12

20

90

12

6

25

40

28

100

19

22

(1)

5

25

13
ESC

Therapeutic cloning

Adult Human SCs from the placenta

Both Human epitheliums and other tissues from SCs

ESC Neuronal SCs for Parkinson's

ESC Pancreatic islet cells for diabetes

Adult Tissue/organ repair-diabetes

ESC Tissue/organ repair-diabetes

ESC

Differentiation pathwaysdiabetes

Tissue/organ regeneration

Adult Hematopoietic SC for cancer and immune disease

Both Therapeutic cloning, drug discovery, xenotransplantation

N/A Cloning-xenotransplantation

Adult Islet cell production for diabetes

Adult Cord blood SC for bone defects and myocardial regeneration

ESC Heart disease, diabetes, banking

Adult Articular cartilage defect

Adult Neurodegenerative disease/damage — neural SCs

Adult Neurological disease/damageneural SCs

Adult CNS disorders-bone marrow $\mathrm{SCs}$

Adult Tissue/organ regenerationhMSCs

ESC Therapeutic cloning-transgenic animals, xenotransplantation

$\mathrm{SC}$ therapy to counter aging

ESC Tissue/organ regeneration; banking

Adult Neurological disease/damage; drug discovery

ESC SC therapy; gene and drug discovery

ESC Neurological disease/damage; gene and drug discovery 
Stem Cell, Inc.

(Palo Alto, CA)

Stem Cell Pharmaceuticals

(Seattle, WA)

StemCell Technologies

(Vancouver, BC, Canada)

Stemron

(Gaithersburg, MD)

StemSource

(Thousand Oaks, CA)

ViaCell

(Boston, MA)

VistaGen

(Burlingame, CA)

\begin{tabular}{|c|c|c|c|}
\hline www.stemcellsinc.com & 28 & Adult & $\begin{array}{l}\text { Tissue/organ regeneration; drug } \\
\text { discovery; gene therapy }\end{array}$ \\
\hline www.stemcellrx.com & 6 & Adult & Tissue/organ regeneration \\
\hline www.stemcell.com & 110 & N/A & $\begin{array}{l}\text { SC isolation, proliferation, } \\
\text { differentiation }\end{array}$ \\
\hline www.stemron.com & 6 & Adult & Tissue/organ regeneration \\
\hline www.stemsource.com & 10 & Adult & Banking $\longrightarrow$ SCs from fat \\
\hline www.viacellinc.com & $\begin{array}{c}128 \\
(160)\end{array}$ & Adult & Cord blood SC therapy; banking \\
\hline www.vistagen-inc.com & 7 & Both & $\begin{array}{l}\text { Drug development; } \mathrm{CNS}, \\
\text { cardiovascular, cancer }\end{array}$ \\
\hline
\end{tabular}

aFor FTE's, numbers in parentheses represent total employees, including those involved in other activites. 